\title{
Formation of stigmasta-3,5-diene in olive oil during deodorization and/or physical refining using nitrogen as stripping gas
}

\author{
By M. León-Camacho, M. Alvarez Serrano and E. Graciani Constante
}

\author{
Instituto de la Grasa. CSIC. Avda. Padre García Tejero, nº 4.-41012 Sevilla.-Spain. \\ Tel.34-54-611550.E-mail:mleon@cica.es
}

\section{RESUMEN}

Formación de estigmasta-3,5-dieno en aceite de oliva durante la desodorización y/o refinación física usando nitrógeno como gas de arrastre.

Durante la refinación física del aceite de oliva, la deshidratación del $\beta$-sitosterol da lugar a la formación del estigmasta-3,5dieno; por consiguiente, una medida de la concentración de estos compuestos permite detectar la presencia del aceite de oliva refinado en los aceites vírgenes. En el presente trabajo se ha estudiado la variación en el contenido de estigmasta-3,5-dieno en el aceite de oliva, durante su refinación física, mediante la utilización de una planta piloto discontinua de $250 \mathrm{Kg}$ de capacidad y empleando nitrógeno como gas de arrastre. Se ha utilizado un diseño experimental $2^{3}$ para estudiar la influencia de las variables independientes del proceso (flujo de nitrógeno, temperatura de trabajo y altura de capa de aceite). Se han determinado el orden aparente de la reacción y la velocidad de formación del estigmasta-3,5-dieno, así como otros parámetros termodinámicos de la misma reacción de deshidratación del $\beta$-sitosterol.

PALABRAS-CLAVE: Aceite de oliva - Análisis por HRGC Desodorización - Formación de estigmasta-3,5-dieno - Refinación física.

\section{SUMMARY}

Formation of stigmasta-3,5-diene in olive oil during deodorization and/or physical refining using nitrogen as stripping gas.

Changes in the content of stigmasta-3,5-diene during industrial physical refining of bleached olive oil were studied in an experimental discontinuous pilot plant of $250 \mathrm{~kg}$ capacity using nitrogen as stripping gas. Dehydratation of $\beta$-sitosterol yields stigmasta-3,5-diene and by means of its quantification it is possible to detect the refined oils in virgin olive oils. A $2^{3}$ experiment was carried out in order to study the relationships among the independent variables involved in the physical refining process (nitrogen flow, temperature and oil load). The apparent kinetic constants (Kap) during the deodorisation process in the formation of stigmasta-3,5-diene were determined. The values of the rate constants and other apparent thermodynamic parameters were determined.

KEY-WORDS: Deodorisation - Formation of stigmasta3,5-diene - HRGC analysis - Olive oil - Physical refining.

\section{INTRODUCTION}

Several hydrocarbons are present in crude oils and fats. The best known is the squalene $(2,6,10,15,19,23-h e x a m e t h y l, \quad$ tetracos-2c,6c,10c,14c, 18c, 22c-hexaene) Gunstone, F. D., et al (1986), which is recognized by its multiple applications and as precursor of triterpenic compounds. This hydrocarbon is present in olive oil where it amounts to an important part of the hydrocarbons fraction (30 and $60 \% \mathrm{w} / \mathrm{w}$ ); the typical content of squalene is between 1250 and $7500 \mathrm{ppm}$ in olive oils.

Other hydrocarbons have been identified in vegetable oils and fats: Capella, P.; et al. 1963 described for the first time the series of saturated hydrocarbons containing between 13-30 atoms of carbon in the virgin olive oil; Eisner, J. et al. 1965 increased the range of saturated hydrocarbons series (15-35 atoms of carbon) and suggested the presence of the series iso and anteiso. They also suggested other series of branching hydrocarbons. Deuel, H.J.Jr. 1951 identified some dienes in the olive oil, such as $\mathrm{C}_{13} \mathrm{H}_{24}$ (oleatridecadiene), $\mathrm{C}_{16} \mathrm{H}_{30}$ (oleahexadecadiene), $\mathrm{C}_{19} \mathrm{H}_{36}$ (oleanonadecadiene); a triene, $\mathrm{C}_{23} \mathrm{H}_{42}$ (oleatricosatriene); a tetraene, $\mathrm{C}_{28} \mathrm{H}_{50}$ (oleaoctacosatetraene) and two saturated, the tetracosane and the hexacosane. The oleatridecadiene might coincide with the 6,10dimethylundecane, identified and quantified by Lanzón, et al. in 1994 and Guinda A. et al, 1996.

The vegetables refined oils are characterized by stigmasta-3,5-diene (Official Journal of the Commission of the European Communities, 1995). The origin of this hydrocarbon, which has been studied by Cert, A., et al., 1994 is the dehydratation of $\beta$-sitosterol during the refining process of edible oils and fats. This hydrocarbon is very interesting to detect the presence of refined oils in crude oils. The European Community has included in his Regulation $\mathrm{N}^{\circ} 656 / 95$ of the Commission, March 1995, a limit in the detection of stigmasta-3,5-diene in the virgin olive oils: this compound must be under $0.15 \mathrm{ppm}$ (Official Journal of the Commission of the European Communities, 1995). Other hydrocarbons originated from the thermal alteration of the sterols present in oils during the refining process have been also detected, for example the campesta-3,5-diene from campesterol [Darren Mennie, et al. (1994)]. 
Sometimes some hydrocarbons may appear during the analysis by gas- chromatography due to the high temperatures and the reductor environment in the chromatographic system. Lanzón, A.; et al. 1992, found a hydrocarbon triterpenic $\mathrm{C} 30 \mathrm{H} 48$ (molecular weight 408) between the alcoholic fraction of the unsaponificable of the olive oil. This hydrocarbon comes from dehydratation of the tertiary alcohol 2,6,10,15,19,23-hexamethylltetracos-3,6,10,14,18,22-hexaen-2-ol, produced in the gas-chromatography.

The aim of this work was to study the kinetics of the formation reaction of stigmasta-3,5-diene in olive oil, and the effect of the different independent variables involved in the deodorisation process, such as time, temperature, flow of stripping gas and the thickness of oil layer, using a pilot plant. To make this study, different experiments of physical refining of olive oil have been carried out, at three different temperatures, with three different flows of stripping gas (nitrogen) and with three oil layers of different thickness using a model $2^{3}$. The results obtained can apply to the deodorisation of other vegetable oils and fats. These studies of reactions haven't been previously performed, however there are other similar studies concerning the isomerisation of fatty acids during the deodorisation and/or physical refining of oils (León Camacho, M. et al, 2001) and the formation-decomposition of waxes (Tubaileh, R.M. et al 2002).

\section{MATERIALS AND METHODS}

\subsection{Samples}

The deodorisation and/or physical refining of each oil, assayed in the experimental pilot plant of $250 \mathrm{~kg}$ maximum capacity per batch (Graciani Constante, E. et al 1994; Ruiz-Méndez, M.V. et al 1996) for discontinuous deodorisation at the Instituto de la Grasa, began by obtaining bleached oils (for later deodorisation) in the way traditionally used in industry to give good final oils.

Bleached olive oil was prepared in the same plant according to the technique described in Graciani Constante, E. et al, 1994. Acidity of the bleached oil was $1.85 \%$ of $\mathrm{ffa}$. Batches were $200 \mathrm{~kg}$.

\subsection{Treatment}

The deodorisation and/or physical refining of the olive oil was carried out in a discontinuous deodorizer of $250 \mathrm{~kg}$ maximum capacity. The equipment and the general technique used in deodorisation and sampling (the latter when the oils reach the working temperature time " 0 " and at $1.5,3$, 4 , and $5 \mathrm{~h}$ of working) are described in Graciani Constante, E. et al 1994 and Ruiz-Méndez, M.V. et al 1996.

The variables of the process were controlled with the following precision: temperature of the oil, $0.5^{\circ} \mathrm{C}$; nitrogen flow, $\pm 0.5 \%$ at scale bottom; thickness of the oil layer, measured in $\mathrm{kg}$, introduced into the deodorizer, $\pm 0.5 \mathrm{~kg}$ and time measured in hours, \pm 1 minute. Table I shows the conditions for each deodorisation. In all cases, the deodorizer was loaded at ambient temperature with bleached oil, the vacuum was produced, and heating to reach the working temperature begun. At $90-100^{\circ} \mathrm{C}$, the stripping gas was introduced. The experimental scheme was a $2^{3}$ centred cube with the same three variables at similar levels (Lacroic, Y., 1962; Dugué, D. and M. Giraul, 1969 and Davies, O.L.:1966).

\subsection{Analytical method}

Stigmasta-3,5-diene. The method for determining the stigmasta-3,5-diene involves isolation using column chromatography by petroleum ether, and quantification by gas chromatography. Stigmasta3,5-diene was purified by column chromatography (Lanzón, A. et al 1992) and quantified by HRGC. The

Table I

Conditions for each deodorisation of olive oil in pilot plant

\begin{tabular}{|c|c|c|c|}
\hline $\mathbf{N}_{\mathbf{2}}$ Flow $\left(\mathbf{m}^{\mathbf{3}} / \mathbf{t} \mathbf{~}\right)$ & $\mathbf{2 4 0}{ }^{\circ} \mathbf{C}$ & $\mathbf{2 5 0}{ }^{\circ} \mathbf{C}$ & $\mathbf{2 6 0}{ }^{\circ} \mathbf{C}$ \\
\hline 1.5 & $125 \mathrm{~kg}$ & & $125 \mathrm{~kg}$ \\
1.5 & $175 \mathrm{~kg}$ & & $175 \mathrm{~kg}$ \\
\hline 2.0 & & $150 \mathrm{~kg}$ & \\
2.0 & & $150 \mathrm{~kg}$ & \\
2.0 & & $150 \mathrm{~kg}$ & \\
\hline 2.5 & $125 \mathrm{~kg}$ & & $125 \mathrm{~kg}$ \\
2.5 & $175 \mathrm{~kg}$ & & $175 \mathrm{~kg}$ \\
\hline
\end{tabular}


quantification by gas chromatography was carried out with HP 5890-II (Hewlett-Packard, Palo Alto, CA) equipped with a split-splitless injector and a flame ionisation detector. A fused silica capillary column HP-5 (30 m x $0.32 \mathrm{~mm}$ i.d., $0.25 \mu \mathrm{m}$ film thickness) (HP 19091J-413) was used, hydrogen (7 psi inlet pressure) being the carrier gas and nitrogen the make-up gas. The oven temperature programming varied. The oven initial temperature was $210^{\circ} \mathrm{C}$ held isothermally $5.0 \mathrm{~min}$. and then raised to $280^{\circ} \mathrm{C}$ at a rate of $3^{\circ} \mathrm{C} / \mathrm{min}$ and held isothermally for $6.67 \mathrm{~min}$. The injector temperature was held at $280^{\circ} \mathrm{C}$ and the detector to $300^{\circ} \mathrm{C}$. The internal standard was cholesta-3,5-diene (Sigma, St. Louis, MO).

Mathematical Analysis. The quantification of the chemical compounds carried out by the HP ChemStation software, version 5.01. Statistica release 5.5 (Statsoft, Tulsa, OK) was used in the statistical analysis.

\section{RESULTS AND DISCUSSION}

The physical refining conditions, oil load, $\mathrm{N}_{2}$ flow and temperature, were fixed from the beginning of each assay. Changes in stigmasta-3,5-diene total contents for the different experimental runs at the end of the heating period and throughout physical refining are summarized in figure 1, figure 2 and figure 3. Analyses of samples taken at zero time may provide information on the changes produced during the previous heating period.

These changes in stigmasta-3,5-diene contents for different runs during the physical refining period were statistically analysed. No significant effects on stigmasta-3,5-diene contents by the independent variables oil load and $\mathrm{N}_{2}$ flow were observed. Table II. Only the temperature produced an important effect during the physical refining.

As a result it should be noted that there aren't any important changes in stigmasta-3,5-diene content caused by distillation during the physical refining of oil. Only the temperature and the operation time during the deodorisation in the physical refining produce an important effect in the content and, therefore in the formation of stigmasta-3,5-diene from $\beta$-sitosterol.

Taking into account the formation of stigmasta-3,5-diene, the study can be quantified during the deodorisation process and their parameters esteemed. The reaction rate $(v)$ at a specific time is, according to the law of mass action, directly proportional to the product of the concentrations of the reactive $\left(\mathrm{C}_{\mathrm{r}}\right)$ involved in the reaction. The power to which each concentration is raised is generally an integer (ai). The constant of proportionality $(\mathrm{k})$ is known as the "specific rate" or "rate constant".

$$
\mathrm{V}=\mathrm{k} \Pi\left(\mathrm{c}_{\mathrm{ri}}\right)^{\mathrm{ai}}
$$

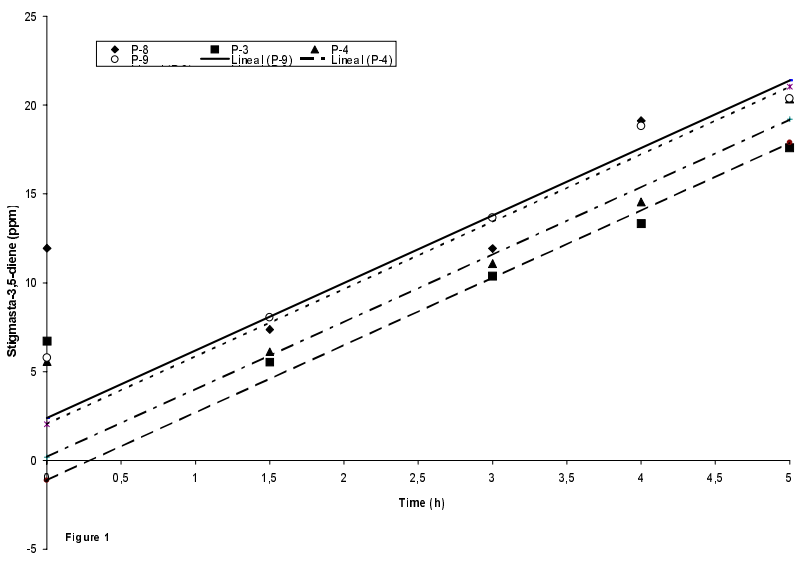

Figure 1

Variation in the concentration (ppm) of stigmasta-3,5-diene conditioned by the operation time at $240^{\circ} \mathrm{C}$ and different flows of stripping gas and thickness of the oil layer.

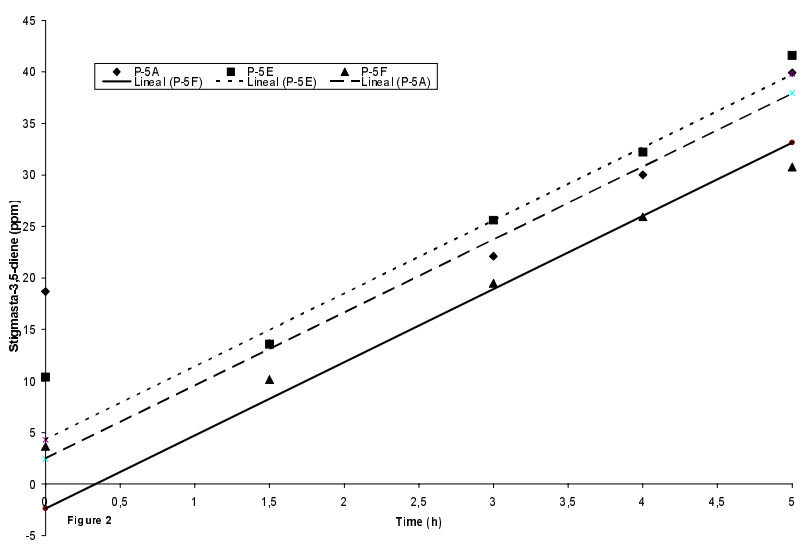

Figure 2

Variation in the concentration (ppm) of stigmasta-3,5-diene conditioned by the operation time at $250^{\circ} \mathrm{C}$ and different flows of stripping gas and thickness of the oil layer

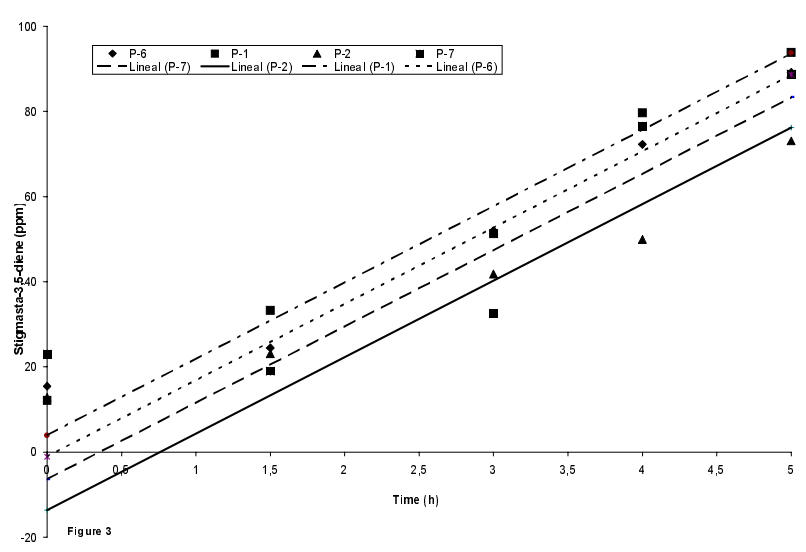

Figure 3

Variation in the concentration (ppm) of stigmasta-3,5-diene conditioned by the operation time at $260^{\circ} \mathrm{C}$ and different flows of stripping gas and thickness of the oil layer. 
Table II

Influence of the independent variables on the results (stigmasta-3,5-diene contents)

\begin{tabular}{|c|c|c|c|}
\hline Time & & Snedecor Law: F & Significance: $p$ \\
\hline \multirow[t]{7}{*}{$\mathrm{Oh}$} & $\mathrm{N}_{2}$ flow (a) & 0.001864 & 0.969482 \\
\hline & Temperature (b) & 2.480865 & 0.255918 \\
\hline & Oil load (c) & 0.007785 & 0.937730 \\
\hline & (a) by (b) & 0.533308 & 0.541177 \\
\hline & (a) by (c) & 0.781846 & 0.469856 \\
\hline & (b) by (c) & 0.312976 & 0.632150 \\
\hline & $(a)^{*}(b) *(c)$ & 0.139568 & 0.744595 \\
\hline \multirow[t]{7}{*}{$1.5 \mathrm{~h}$} & $\mathrm{~N}_{2}$ flow (a) & 6.5247 & 0.125135 \\
\hline & Temperature (b) & 167.2307 & $0.005927\left(^{*}\right)$ \\
\hline & Oil load (c) & 0.7310 & 0.482624 \\
\hline & (a) by (b) & 9.0352 & 0.095146 \\
\hline & (a) by (c) & 2.5879 & 0.248954 \\
\hline & (b) by (c) & 0.6773 & 0.497017 \\
\hline & $(a)^{*}(b)^{*}(c)$ & 8.6965 & 0.098322 \\
\hline \multirow[t]{7}{*}{$3 \mathrm{~h}$} & $\mathrm{~N}_{2}$ flow (a) & 9.3000 & 0.092802 \\
\hline & Temperature (b) & 225.5418 & $0.004404\left(^{*}\right)$ \\
\hline & Oil load (c) & 1.0631 & 0.410868 \\
\hline & (a) by (b) & 13.0194 & 0.068958 \\
\hline & (a) by (c) & 0.2617 & 0.659865 \\
\hline & (b) by (c) & 1.6075 & 0.332464 \\
\hline & $(a)^{*}(b)^{*}(c)$ & 2.1345 & 0.281483 \\
\hline \multirow[t]{7}{*}{$4 \mathrm{~h}$} & $\mathrm{~N}_{2}$ flow (a) & 7.3843 & 0.112939 \\
\hline & Temperature (b) & 552.5920 & $0.001805\left(^{*}\right)$ \\
\hline & Oil load (c) & 12.9146 & 0.069461 \\
\hline & (a) by (b) & 8.5063 & 0.100201 \\
\hline & (a) by (c) & 10.5096 & 0.083418 \\
\hline & (b) by (c) & 15.4453 & 0.059066 \\
\hline & $(a)^{*}(b)^{*}(c)$ & 1.0317 & 0.416652 \\
\hline
\end{tabular}

(*) Statistical significant effects

By definition, the rate order is the sum of the powers which appear in the above expression. At the same time, each power (ai) is known as partial order (with respect to substance, ri). There are several mathematical and graphical procedures to determine the order. The rate order should be equal to 1 , which gives the lowest variance and the highest correlation coefficient (Rodríguez Velasco, J. et al 1975).
In the present work, according to the figures 1,2 and 3 , the rate order which better adapts to the results obtained during the process of physical refining of the olive oil, in the time interval studied of the deodorization ( between 0 and $5 \mathrm{~h}$ ), is " 0 ".

$$
c_{r i}=k \text { *t }
$$


Table III

Order (according to the hypothesis established) within the interval of the temperatures studied for the formation of stigmasta-3,5-diene in the physical refining of olive oil as well as the corresponding values of "k" and " $\Delta \mathbf{G}^{\neq}$"

\begin{tabular}{|c|c|c|c|c|c|c|}
\hline \multirow[b]{2}{*}{$\begin{array}{c}\text { Temperature } \\
{ }^{\circ} \mathrm{K}\end{array}$} & \multirow{2}{*}{$\begin{array}{l}\text { Attributed } \\
\text { order of } \\
\text { reaction }\end{array}$} & \multicolumn{2}{|c|}{$k\left(p p m h^{-1}\right)$} & \multicolumn{2}{|c|}{$k\left(\mathrm{mols}^{-1} \mathrm{~s}^{-1}\right)$} & \multirow[b]{2}{*}{$\begin{array}{c}\Delta \mathrm{G}^{\neq} \\
\left(\mathrm{kcal} \mathrm{mol}{ }^{-1}\right)\end{array}$} \\
\hline & & & $\begin{array}{c}\text { Typical } \\
\text { error }\end{array}$ & & $\begin{array}{c}\text { Typical } \\
\text { error }\end{array}$ & \\
\hline 513.16 & 0 & 3.9 & $<0.2$ & $2.210^{-9}$ & $<110^{-10}$ & -74.4 \\
\hline 523.16 & 0 & 7.1 & $<0.5$ & $3.910^{-9}$ & $<310^{-10}$ & -75.3 \\
\hline 533.16 & 0 & 18.0 & 2.8 & $9.910^{-9}$ & $210^{-9}$ & -75.7 \\
\hline
\end{tabular}

Table IV

Estimated values of $\mathrm{E}^{\neq}, \mathrm{A}, \Delta \mathrm{H}^{\neq}$and $\Delta \mathrm{S}^{\neq}$in physical refining of olive oil $\left(240^{\circ} \mathrm{C}-260^{\circ} \mathrm{C}\right.$.

\begin{tabular}{|c|c|c|c|}
\hline $\mathrm{E}^{ \pm}\left(\mathrm{kcal} . \mathrm{mo}^{-1}\right)$ & $\mathrm{A}\left(\mathrm{mol} \mathrm{l}^{-1} \mathrm{~s}^{-1}\right)$ & $\Delta \mathrm{H}^{ \pm}\left(\mathrm{kcal}^{\mathrm{mol}} \mathrm{m}^{-1}\right)$ & $\begin{array}{c}\Delta \mathrm{S}^{ \pm} \\
\left(\mathrm{kcal} \mathrm{mol}{ }^{-1} \mathrm{~K}^{-1}\right)\end{array}$ \\
\hline$-9.9 \mathrm{E}-05$ & 1.00 & -41.1 & 0.065 \\
\hline
\end{tabular}

Where $t$ is the time when the oil reaches the working temperature.

The use of "zero time" sample in the calculations is unsuitable, since it may considerably increase the variance of the results. That might be because the temperature cannot be held totally constant throughout the bulk of the oil at that moment, despite of the stirring produced by the nitrogen flow.

To estimate the values of the rate constants squared minimum fits were performed (Dugué, D. and M. Giraul, 1969). For these proposals, the data obtained in all of the different deodorizations carried out in the pilot plant were used, taking $5 \mathrm{~h}$ as maximum time (it is assumed that no industrial deodorisation will take longer).

Or the other hand, it is possible to assume that the different deodorizations carried out with a single type of oil at same working temperatures were independent repetitions, although they had layers of different thickness and stripping gas flow. The straight lines obtained in each individual fit are parallel, and they perform the fit with such a restriction since the differences found could be attributed to randomness (León-Camacho, M., 2001). No significant effects on stigmasta-3,5-diene contents by the independent variables oil load and N2 flow, were observed.

Arrhenius established the dependence of the reaction rate with the temperature (Pannetier, G. And Souchay, P. 1964; Castellan, G. W. 1976):

$$
k=A^{*} \exp \left(-E^{\neq} / R K\right)
$$

In which the constant $A$ is termed the "frequency factor" or "pre-exponential factor" and Ec is the "activation energy".

Expressing this equation logarithmically:

$$
\operatorname{Ln}(k)=\operatorname{Ln}(A)-E^{\neq} / R K
$$

Estimating the rate constant $(\mathrm{k})$ at different temperatures $\left(240^{\circ} \mathrm{C}, 250^{\circ} \mathrm{C}\right.$ and $\left.260^{\circ} \mathrm{C}\right)$, the values of $A$ and $\mathrm{E}^{\neq}$can be calculated. And the values are included in tables III and IV.

For a reaction such as stigmasta-3,5-diene formation, and since the reaction occurs at constant temperature and pressure $(3 \mathrm{~mm} \mathrm{Hg})$ throughout the deodorisation period, where the results experimentally demonstrate that the order of reaction can be considered " 0 " within the studied interval. The values of $\Delta \mathrm{G}^{\neq}$(increment of Gibbs activation energy), $\Delta \mathrm{S}^{\neq}$(increment of activation entropy) and $\Delta \mathrm{H}^{\neq}$ (increment of activation enthalpy) can be calculated or estimated from the values found for the rate constant (Castellan, G. W., 1976):

$$
\begin{gathered}
K=k_{B} / h \exp (-\Delta G / R K) \\
\Delta G^{\neq}=\left[\operatorname{Ln}(k)-\operatorname{Ln}\left(k_{B}{ }^{*} K / h\right)\right]{ }^{*} R K
\end{gathered}
$$

and by the equation (Rodríguez Velasco, J. et al, 1975):

$$
\Delta \mathrm{G}^{\neq}=\Delta \mathrm{H}^{\neq}-\mathrm{K}^{*} \Delta \mathrm{S}^{\neq}
$$


Where

$\mathrm{K}=$ Absolute temperature. $={ }^{\circ} \mathrm{C}+273.16 \pm 0.01 \mathrm{~K}(19)$

$\mathrm{R}=1.987 \mathrm{cal}^{\circ} \mathrm{K}^{-1} \mathrm{~mol}^{-1}=(8.3166+0.0004) \mathrm{E} 07 \mathrm{erg}$

$\mathrm{K}^{-1} \mathrm{~mol}^{-1}(19)$

$\mathrm{K}_{\mathrm{B}}=$ Bolzmann constant $=1.3802610^{-6} \mathrm{erg} \mathrm{K}^{-1}$ (19)

$\mathrm{h}=$ Planck constant $=(6.6252 \pm 0.0005) 10^{-27}$ erg s (19)

$\mathrm{k}=$ rate constant

Table 3 shows the estimated values of "k" and $\Delta \mathrm{G}^{\neq}$, assuming that the assays performed at the same temperature are considered as replications. To calculate these data, one must express the "k" of the reaction in mol $\mathrm{l}-1 \mathrm{~s}-1$, using $0.797,0.793$, and 0.788 $\mathrm{g} \mathrm{ml}-1$ at $240^{\circ} \mathrm{C}, 250^{\circ} \mathrm{C}$ and $260^{\circ} \mathrm{C}$ respectively, as olive oil density. The molecular weight of the stigmasta-3,5-diene ( $\mathrm{g} \mathrm{mol}-1)$ is the molecular weight of the $\beta$-sitosterol (414.713 $\mathrm{g} \mathrm{mol}^{-1}$ ) [Gunstone, F.D. et al (1986)], molecular weight of the water $\left(18 \mathrm{~g} \mathrm{~mol}^{-1}\right)$.

Estimated values of $E^{\neq} A, \Delta H^{\neq}$and $\Delta S^{\neq}$, for the values of $\mathrm{k}$ found, are shown in table IV.

\section{ACKNOWLEDGEMENTS}

The authors would like to thank the staff members of the Instituto de la Grasa for their work and support; the factories "Aceites Toledo", "Aceprosa", "Bush Ibérica S.A" and "Carburos Metálicos S.A" for supplying the oils and technology necessary to carry out this investigation and CICYT( Ministry of Education and Science of Spain) for their financial support (ALI 91-7020) (PTR 93-0061) and (ALI 94-0716).

\section{REFERENCES}

Gunstone, F. D.; Harwood, J.L. And Padley, F. B. (1986), The Lipid Handbook. Dictionary section. Ed. Chapman and Hall. ISBN 041224480 2, 223.

Capella, P.; Fedeli, E.; Cirimele, M.; Jacini, G. (1963) Riv. It. Sost. Grasse. 40, 603.

Castellan, G. W. 1976, Fisicoquímica, 2a Eidición. Ed. Fondo Educativo Interamericano S.A. Bogotá, Brasil.

Cert, A.; Lanzón, A.; Carelli, A.; Albi, T.; Amelotti, G. (1994). Formation of stigmas - 3-, 5-diene in vegetable oils. Food Chemistry. 49, , 287-293.

Davies, O.L.:1966 Métodos estadísticos aplicados a la industria química, Ed. Aguilar, Barcelona .

Darren Mennie, Colin F., Moffat, and Alister S. McGill. (1994). Identification of Sterene Compounds Produced During the Processing of Edible Oils. Journal of High Resolution Chromatography 17 831-838.

Deuel, H. J. Jr. (1951), The lipids. Their chemistry and biochemistry. Vol. I: Chemistry. Interscience Publishers, Ins., New York, 305-404.
Dugué, D. and M. Giraul, 1969; Analyse de variance et plans dexpérience, Deuxiéme Edition, Ed. Dunod, Paris.

Eisner, J.; Iverson, J.L.; Mozingo, A.K.; Firestoene, D. (1965) J. A. O. A. C. 48, , 417.

Graciani Constante, E., F.C. Rodríguez Berbel, and M.V. Ruiz Méndez, (1994) Physical refining of edibles Oils using nitrogen as stripping gas, Grasas y Aceites 45 132-146.

Guinda, A.; Lanzón, A.; Albi, T. (1996). Differences in Hydrocarbons of Virgin Olive Oils Obtained from Several Olive Varieties. J. Agr. Food Chem., 44, 1723-1726.

Gunstone, F.D.; Harwood, J.L. and Padley, F.B. (1986), The Lipid Handbook. Dictionanary Section. Ed. Chapman and Hall. London and New York. 224.

Lacroic, Y.: 1962 Analyse chimique, interprétation des résultats par le calcul statisque, Masson et Cie, Editeurs, Paris.

Lanzón, A.; Albi, T.; Cert, A. y Gracián, J. (1994). The Hydrocarbon fraction of virgin olive oil and changes resulting from refining. J. Am. Oil Chem. Soc. 71, 285-291.

Lanzón, A.; Albi, T.; Cert, A y Gracian, J. (1992). Componentes del insaponificable del aceite de oliva con polaridad comprendida entre el escualeno y los alcoholes triterpénicos. Grasas y Aceites, 43, 271-276.

León Camacho, M.; Ruiz Méndez, MํV.; Graciani Constante, Mㄹ. M. and Graciani Constante, E. (2001). Kinetics the cis-trans isomerization of linoleic acid in the deodorization and /or physical refining of edible fats. Eur. J. Lipid Sc.. Technol. 103 85-92.

León-Camacho, M.; Ruiz-Méndez, Mạ.V.; Graciani Constante, Ma.M. and Graciani Constante, E. (2001). Kinetics of the cis-trans isomerization of linoleic acid in the deodorization and/or physical refining of edible fats. Eur. J. Lipid Sic. Technol. 103, 85-92.

Official Journal of the Commission of the European Communities (EC) (1995). Regulation No 656/95, L 69/2, Marz 29, 1995.

Pannetier, G. And Souchay, P. (1964) Chimie Générale. Cinétique chimique. Ed. Masson et Cie, Paris.

Rodríguez Velasco, J.; Sánchez Burgos, F. And Domínguez Pérez, M. 1975, Lecciones de cinética química. Ed. Publicaciones de la Universidad de Sevilla.

Ruiz-Méndez, M.V., A. Garrido Fernández, F.C. Rodríguez Berbel and E. Graciani constante, (1996) Relationships among the variables involved in the physical refining of olive oil using nitrogen as stripping gas, Fett Lipid 98 121-125.

Tubaileh, R.M., Graciani Constante, Ma.M.; León Camacho, M.; López López, A and Graciani Constante, E. (2002). Kinetics of the decomposition of total aliphatic waxes in olive oil during deodorization. J.A.O.C.S. 79 (2002) 971-976. 